\title{
Evaporation Mechanism of Sn and SnS from Liquid Fe: Part III. Effect of $\mathrm{C}$ on Sn Removal
}

\author{
SUNG-HOON JUNG, YOUN-BAE KANG, JEONG-DO SEO, JOONG-KIL PARK, \\ and JOO CHOI
}

\begin{abstract}
To understand the effect of $\mathrm{C}$ on Sn evaporation from liquid iron in the view of ferrous scrap recycling, the evaporation of $\mathrm{Sn}$ from various liquid $\mathrm{Fe}-\mathrm{C}-\mathrm{S}-\mathrm{Sn}$ alloys was experimentally investigated. A series of gas-liquid reactions was carried out at $1873 \mathrm{~K}\left(1600{ }^{\circ} \mathrm{C}\right)$ using an electromagnetic levitation melting technique, where mass transfers in gas phase and liquid phase did not significantly affect the reaction rate. It was found that $\mathrm{CS}_{2}(\mathrm{~g})$ is a major gas species evaporating from Fe-C-S alloy (initial S content [pct S] $]_{0}: 0.028$ to 0.502 mass pct), and Fe-C-SSn alloy ([pct $S]_{0}: 0.063$ to 0.560 mass pct), thereby competing with $\mathrm{SnS}$ for $\mathrm{S}$ in the liquid alloy. A model equation for the evaporation rate of $\mathrm{CS}_{2}(\mathrm{~g})$ was established using the experimental data for the Fe-C-S alloys. The chemical reaction rate constant for the $\mathrm{CS}_{2}(\mathrm{~g})$ evaporation $\left(k_{\mathrm{CS} 2}^{\mathrm{R}}\right)$ was obtained as $4.24 \times 10^{-12} \mathrm{~m}^{7} \mathrm{~mol}^{-2} \mathrm{~s}^{-1}$, and the residual rate constant $\left(k_{\mathrm{CS} 2}^{\mathrm{r}}\right)$ was $4.24 \times 10^{-16}$ $\mathrm{m}^{7} \mathrm{~mol}^{-2} \mathrm{~s}^{-1}$, both at $1873 \mathrm{~K}\left(1600^{\circ} \mathrm{C}\right)$. Roll of $\mathrm{C}$ on the evaporation of $\mathrm{Sn}$ in Fe-C-Sn alloy was confirmed to be the increase of activity coefficient of Sn. By taking into account (1) the evaporation of $\mathrm{Sn}(\mathrm{g}), \mathrm{SnS}(\mathrm{g})$, and $\mathrm{CS}_{2}(\mathrm{~g})$, and (2) the increasing activity coefficient of $\mathrm{Sn}$ and $\mathrm{S}$ by $\mathrm{C}$, a comprehensive model for the evaporation rate of $\mathrm{Sn}$ and $\mathrm{S}$ in the Fe-C-Sn-S alloy was developed. The calculation results by the developed model in the present study showed good agreement with the experimental results. Some applications of the current model are presented in the view of increasing the Sn removal rate.
\end{abstract}

DOI: $10.1007 / \mathrm{s} 11663-014-0220-\mathrm{y}$

(C) The Minerals, Metals \& Materials Society and ASM International 2014

\section{INTRODUCTION}

To discover an effective use of ferrous scrap as an alternative iron source instead of iron ore, much research has been carried out to develop a technology for the economic and effective use of the ferrous scrap. However, some tramp elements such as $\mathrm{Cu}, \mathrm{Sn}, \mathrm{Ni}$, and $\mathrm{Zn}$, found in ferrous scrap are known to cause contamination of the recycled steel, and the presence of those tramp elements hinders active recycling of the ferrous scrap.

Among those tramp elements, $\mathrm{Sn}$ is found in the ferrous scrap mainly as the form of tinplate. Sn, if it enters in steel products, leads to deterioration of drawing and forming properties by a loss of ductility of steel. Therefore, the Sn content in steel is strictly controlled. ${ }^{[1]}$

To minimize the undesirable aspect of $\mathrm{Sn}$, various removal methods have been proposed. In particular, $\mathrm{Sn}$ removal by vacuum distillation has been actively investigated, thanks to the availability of vacuum facilities in most of steelmaking plants. Basically, $\mathrm{Sn}$ in the liquid

SUNG-HOON JUNG, Graduate Student, and YOUN-BAE KANG, Associate Professor, are with the Graduate Institute of Ferrous Technology, Pohang University of Science and Technology, Pohang, Kyungbuk, 790-784, Republic of Korea. Contact e-mail: ybkang@ postech.ac.kr JEONG-DO SEO, Senior Principal Researcher, JOONG-KIL PARK and JOO CHOI, Group Leaders, are with the Steelmaking Research Group, Technical Research Laboratories, POSCO, Pohang, Kyungbuk, 790-785, Republic of Korea.

Manuscript submitted August 5, 2014.

Article published online October 31, 2014. steel evaporates to gas phase due to the difference in the vapor pressures of $\mathrm{Fe}$ and $\mathrm{Sn}$. Previous research for the Sn evaporation mainly focused on (1) the Sn evaporation reaction mechanism and (2) maximizing the evaporation rate of $\mathrm{Sn}$. It was revealed that $\mathrm{S}$ could enhance the evaporation rate of Sn significantly, and the degree of vacuum is also a key factor to increase the evaporation rate. ${ }^{[2-8]}$ Also, the effect of alloying elements on Sn evaporation rate has been investigated. ${ }^{[7-13]}$

Although it has been understood that Sn can evaporate from liquid steel in the form of $\mathrm{SnS}(\mathrm{g})$ gas species, only a qualitative interpretation was available in the literature. The evaporation rate of Sn could not be well represented. In the present authors' previous study, it was elucidated for the first time that $S$ plays two opposite roles for the evaporation of $\mathrm{Sn}$ from the liquid steel: (1) $S$ enhances the evaporation of $\mathrm{Sn}$ by forming $\mathrm{SnS}(\mathrm{g})$ gas species, which has significantly higher vapor pressure than $\mathrm{Sn}(\mathrm{g})$, and (2) $\mathrm{S}$ retards the evaporation of Sn by blocking the reaction sites, both for $\mathrm{Sn}(\mathrm{g})$ and $\mathrm{SnS}(\mathrm{g}) .{ }^{[14,15]}$ It was also found that there are residual sites for the evaporation that could not be blocked by the S. ${ }^{[15]}$ Taking into account all these facts, a comprehensive evaporation model for the $\mathrm{Sn}$ in Fe-S-Sn alloy was developed, and it has been validated by the present authors' own experiment for alloys having 0 to 0.894 mass pet of S content at $1873 \mathrm{~K}\left(1600{ }^{\circ} \mathrm{C}\right) .{ }^{[15]}$

In the actual scrap recycling process, a mix of hot metal and ferrous scrap would be sought to have some heat source. Therefore, a high $\mathrm{C}$ content in the mixed 
steel is inevitable, so it is required to understand the role of $\mathrm{C}$ on the mechanism and rate of $\mathrm{Sn}$ evaporation. As it has been clarified that $\mathrm{Sn}$ evaporates as $\mathrm{Sn}(\mathrm{g})$ and $\mathrm{SnS}(\mathrm{g}),{ }^{[14,15]}$ it is necessary to understand how $\mathrm{C}$ affects the evaporation of $\mathrm{Sn}(\mathrm{g})$ and $\mathrm{SnS}(\mathrm{g})$, respectively. It has also been known that $\mathrm{C}$ increases the activity coefficients of $\mathrm{Sn}$ and $\mathrm{S}$ in liquid iron. ${ }^{[16]}$

The main purpose of the present study is to investigate the fundamentals of the evaporation reaction of $\mathrm{Sn}$ from Fe-C-S-Sn alloys representing a mixture of hot metal and ferrous scrap containing Sn. Therefore, experiments for evaporation reactions in several Fe-C$\mathrm{S}-\mathrm{Sn}$ liquid alloys were conducted in the present study. To elucidate the reaction mechanism in more detail, some experiments in subsystems (Fe-C-S, Fe-C-Sn) were also carried out. Along with the conclusions derived from the present authors' previous investigations, ${ }^{[14,15]}$ the evaporation model equation already developed ${ }^{[15]}$ was expanded in the present study to incorporate the role of $\mathrm{C}$ for the evaporation of $\mathrm{Sn}$. The evaporation model was then validated by the experimental results obtained in the present study. To clearly distinguish terms used throughout this article, "evaporation of $\mathrm{Sn}(\mathrm{g})$ " is used to mean the evaporation of $\mathrm{Sn}$ in the form of $\mathrm{Sn}(\mathrm{g})$ exclusively. Similarly, "evaporation of $\mathrm{SnS}(\mathrm{g})$ ", is used only for the evaporation of $\mathrm{Sn}$ in the form of $\mathrm{SnS}(\mathrm{g})$. "Overall evaporation rate" is used to refer evaporation rate of $\mathrm{Sn}$ in both forms, $\mathrm{Sn}(\mathrm{g})$ and $\mathrm{SnS}(\mathrm{g})$.

\section{EXPERIMENTAL}

A series of gas-liquid reactions was carried out to measure the reaction rate of $\mathrm{Sn}$ evaporation under the condition where mass transfers in gas phase and liquid phase do not significantly limit the rate. The experimental details are almost similar to those employed in the previous studies of the present authors. ${ }^{[14,15]}$ Only a brief summary of experimental details is described next.

\section{A. Sample Preparation}

Several alloys made of Fe-C-S, Fe-C-Sn, and Fe-C-SSn were prepared in an induction-melting furnace under a purified Ar atmosphere. Electrolytic iron with powder of FeS (99.9 mass pct., Strem Chemicals, Newburyport, MA) and/or granule of Sn (99.99 mass pct., RND Korea Company, Kwangmyung, Korea) were melted in graphite crucibles at $1873 \mathrm{~K}\left(1600{ }^{\circ} \mathrm{C}\right)$. Small portions of the melt were sampled by quartz tubes to obtain bars of $4 \times 10^{-3} \mathrm{~m}$ diameter. Samples for the evaporation experiment using an electromagnetic levitation technique were prepared by cutting and grinding those bars into small pieces (approximately to the weight of $\left.6 \pm 0.1 \times 10^{-4} \mathrm{~kg}\right)$.

\section{B. Experimental Procedure and Chemical Analysis}

The experimental equipment and procedure used in the present study are the same as those given in the previous articles. ${ }^{[14,15]}$ An electromagnetic levitation technique was used by an radio frequency (RF) signal generator $(30 \mathrm{~kW}, 260 \mathrm{kHz})$ to make the reaction between the gas and liquid alloy. During the levitation and melting, an Ar-4 pet $\mathrm{H}_{2}$ gas mixture was flown into the reaction chamber made of a quartz tube (inner diameter: $18 \mathrm{~mm}$ ) to prevent accidental oxidation during the experiment. The flow rate of deoxidized gas mixture was kept at $1 \mathrm{~L} \mathrm{~min}^{-1}$, but it was varied in some experiments. The temperature of the levitated droplet was controlled manually and was measured by a twocolor pyrometer. In the current study, all experiments were carried out at $1873 \mathrm{~K} \pm 10 \mathrm{~K}\left(1600{ }^{\circ} \mathrm{C} \pm 10{ }^{\circ} \mathrm{C}\right)$. After a predetermined time was passed, the droplet was quenched into a water in a copper mold.

Sn concentrations of the samples were analyzed by inductively coupled plasma spectrometer (Thermo Scientific ICAP 6500, Waltham, MA), and the $\mathrm{C}$ and $\mathrm{S}$ concentrations were analyzed by the $\mathrm{C} / \mathrm{S}$ combustion analysis method (LECO CS844, St. Joseph, MI).

All experimental conditions employed in the current study are listed in Table I.

\section{PRELIMINARY TEST OF SN EVAPORATION IN FE-C-SN-S LIQUID}

As mentioned in Section I, presence of $\mathrm{C}$ in liquid steel is expected to increase the $\mathrm{Sn}$ evaporation rate by increasing activity coefficients of $\mathrm{Sn}$ and $\mathrm{S}$ in the steel. ${ }^{[10]}$ This increases driving force for the evaporation reaction of $\operatorname{Sn}(\mathrm{g})$ and $\operatorname{SnS}(\mathrm{g})$ via:

$$
\mathrm{Sn}=\mathrm{Sn}(\mathrm{g})
$$

and

$$
\mathrm{Sn}+\mathrm{S}=\mathrm{SnS}(\mathrm{g})
$$

respectively. To investigate the effect of $\mathrm{C}$ on $\mathrm{Sn}$ evaporation rate, a preliminary test was conducted with a Fe-C-S-Sn liquid alloy. Changes of [pet Sn] and [pct S] in the Fe-C-S-Sn liquid alloy measured in the present study are shown in Figure 1, along with those measured for the alloy in the absence of $\mathrm{C}$ (Fe-S-Sn liquid alloy) reported in the previous study. ${ }^{[14]}$ The initial concentrations of $\mathrm{Sn}$ and $\mathrm{S}$ ([pct $\mathrm{Sn}]_{0}$ and $[\text { pct } \mathrm{S}]_{0}$ ) were similar $\left([\text { pct } \mathrm{Sn}]_{0}=0.188 \text { vs. 0.231, [pct S }\right]_{0}=0.062$ vs. 0.054). As seen in the figure, it is evident that [pct Sn] and [pct S] decreased considerably faster when $\mathrm{C}$ existed. It is confirmed that $\mathrm{C}$ accelerates evaporation of $\mathrm{Sn}$, probably to the form of $\operatorname{SnS}(\mathrm{g}),{ }^{[10]}$ and this may be due to the increase of the activity coefficients of $\mathrm{Sn}$ and $\mathrm{S}$.

However, before any detailed analysis regarding the increase of activity coefficients by $\mathrm{C}$, an unexpected result was observed - that [pct S] decreased more than what was expected. According to the previous investigations, ${ }^{[14,15]}$ the number of moles of removed $\mathrm{S}\left(\Delta n_{\mathrm{S}}\right)$ is to be almost the same as the number of moles of removed $\mathrm{Sn}\left(\Delta n_{\mathrm{Sn}}\right)$, if $\mathrm{Sn}$ evaporates exclusively as $\operatorname{SnS}(\mathrm{g})$, or at least less than $\Delta n_{\mathrm{Sn}}$ if $\operatorname{Sn}(\mathrm{g})$ and $\operatorname{SnS}(\mathrm{g})$ evaporate simultaneously. Therefore, $\Delta n_{\mathrm{S}}$ is less than $\Delta n_{\mathrm{Sn}}$. However, [pct S] assuming $\Delta n_{\mathrm{S}}=\Delta n_{\mathrm{Sn}}$, which corresponds to the maximum amount of $\mathrm{S}$ being able to be evaporated, as shown by a dashed line, is higher than 
Table I. Experimental Conditions Employed in the Present Study

\begin{tabular}{|c|c|c|c|c|c|c|c|c|}
\hline Exp. No. ${ }^{*}$ & Flow Rate, $\mathrm{L} \min ^{-1}$ & {$[\text { pct Sn }]_{0}$} & {$[\text { pct } S]_{0}$} & {$[\text { pct } \mathrm{C}]_{0}$} & Mass, $\mathrm{kg}$ & $\begin{array}{l}\text { Density, } \\
\mathrm{kg} \mathrm{m}^{-3}\end{array}$ & \multicolumn{2}{|c|}{ Dimension of Droplet } \\
\hline $\mathrm{S} 1$ & 1.00 & 0 & 0.063 & 0 & & & & \\
\hline $\mathrm{CS} 1$ & 0.25 & 0 & 0.068 & 4.85 & & & & \\
\hline $\mathrm{CS} 2$ & 0.50 & 0 & 0.068 & 4.85 & & & & \\
\hline CS3 & 0.80 & 0 & 0.068 & 4.85 & & & & \\
\hline CS4 & 1.00 & 0 & 0.068 & 4.85 & & & & \\
\hline CS5 & 1.25 & 0 & 0.068 & 4.85 & & & & \\
\hline CS6 & 1.50 & 0 & 0.068 & 4.85 & & & & \\
\hline CS7 & 1.00 & 0 & 0.028 & 5.25 & & & & \\
\hline CS8 & 1.00 & 0 & 0.035 & 5.02 & & & & \\
\hline CS9 & 1.00 & 0 & 0.192 & 4.80 & & & & \\
\hline CS10 & 1.00 & 0 & 0.293 & 4.81 & & & Radius, m & $2.74 \times 10^{-3}$ \\
\hline CS11 & 1.00 & 0 & 0.502 & 4.82 & $6 \pm 0.1 \times 10^{-4}$ & 7000 & Surface, $\mathrm{m}^{2}$ & $9.40 \times 10^{-5}$ \\
\hline CSn 1 & 1.00 & 0.195 & $0.0004^{* *}$ & 5.11 & & & Volume, $\mathrm{m}^{3}$ & $8.57 \times 10^{-8}$ \\
\hline $\mathrm{CSnS} 1$ & 1.00 & 0.231 & 0.054 & 5.08 & & & & \\
\hline $\mathrm{CSnS} 2$ & 0.25 & 0.162 & 0.063 & 5.13 & & & & \\
\hline $\mathrm{CSnS} 3$ & 0.50 & 0.162 & 0.063 & 5.13 & & & & \\
\hline $\mathrm{CSnS} 4$ & 1.00 & 0.162 & 0.063 & 5.13 & & & & \\
\hline CSnS5 & 1.50 & 0.162 & 0.063 & 5.13 & & & & \\
\hline CSnS6 & 2.00 & 0.162 & 0.063 & 5.13 & & & & \\
\hline CSnS7 & 1.00 & 0.190 & 0.104 & 5.13 & & & & \\
\hline CSnS8 & 1.00 & 0.220 & 0.224 & 4.97 & & & & \\
\hline CSnS9 & 1.00 & 0.212 & 0.320 & 4.88 & & & & \\
\hline CSnS10 & 1.00 & 0.201 & 0.560 & 4.92 & & & & \\
\hline
\end{tabular}

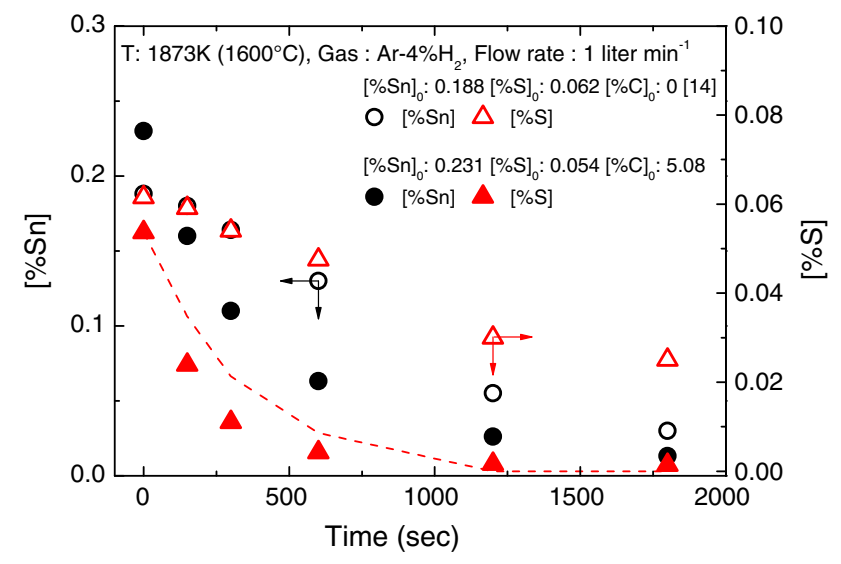

Fig. 1-Decrease of [pct Sn] and [pct S] in liquid alloys at $1873 \mathrm{~K}$ $\left(1600{ }^{\circ} \mathrm{C}\right)$ : open symbols for Fe-S-Sn alloy and closed symbols for Fe-C-S-Sn alloy. A dashed line is estimated [pct S] of the Fe-C-S-Sn alloy assuming $\mathrm{S}$ is evaporated solely as $\mathrm{SnS}(\mathrm{g})$, to be compared with closed triangle.

what was experimentally determined in the early stage of the evaporation. It is shown more clearly in Figure 2 by comparing the number of moles of $\mathrm{S}$ and $\mathrm{Sn}$ removed from the alloys, with or without $\mathrm{C}$. In the presence of $\mathrm{C}$, $\Delta n_{\mathrm{S}}$ was higher than $\Delta n_{\mathrm{Sn}}$ in the early stage of the reaction. This finding implies that $\mathrm{S}$ in the liquid alloy had been lost in some additional way apart from $\mathrm{SnS}(\mathrm{g})$. On the other hand, if there was no $\mathrm{C}$, then $\Delta n_{\mathrm{S}}$ was almost the same as the $\Delta n_{\mathrm{Sn}}$, representing evaporation primarily in the form of $\mathrm{SnS}(\mathrm{g})$ in the early stage of the reaction. This finding suggests that a detailed investiga-

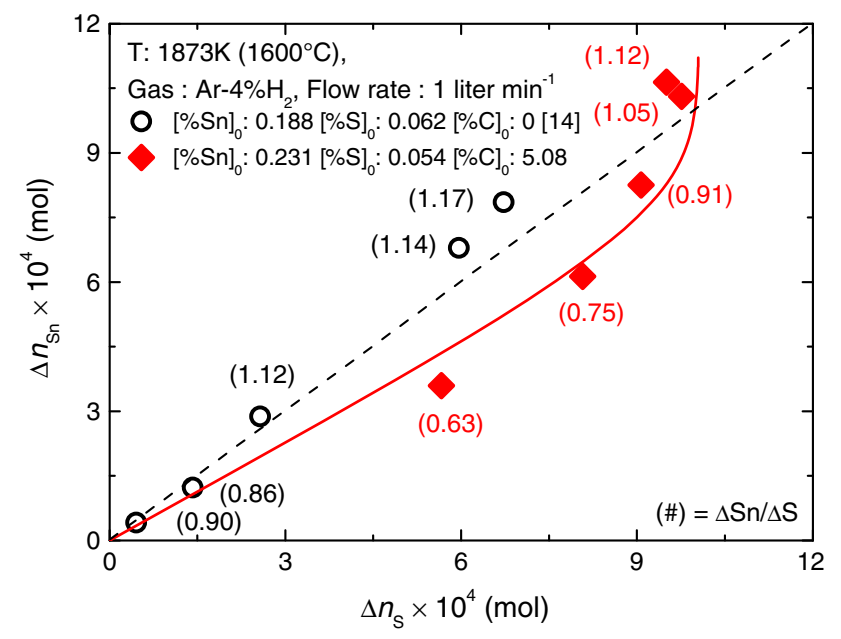

Fig. 2-Number of moles of $\mathrm{S}$ and $\mathrm{Sn}$ removed from the liquid alloys (mass of the alloys $=6 \times 10^{-4} \mathrm{~kg}$ ) at $1873 \mathrm{~K}\left(1600^{\circ} \mathrm{C}\right.$ ) shown in Fig. 1: open circles for the Fe-S-Sn alloy and closed diamonds for the Fe-C-S-Sn alloy. A solid line is the calculated relationship between $\Delta n_{\mathrm{S}}$ and $\Delta n_{\mathrm{Sn}}$ from Eqs. [17] and [18].

tion of $\mathrm{S}$ evaporation in the presence of $\mathrm{C}$ be carried out because the $\mathrm{S}$ plays very important role for the $\mathrm{Sn}$ evaporation.

In the following sections, the role of $\mathrm{C}$ on the evaporation of $\mathrm{Sn}$ from liquid alloy is presented as follows. Section IV reports the effect of $\mathrm{C}$ on the evaporation of $\mathrm{Sn}$ in the absence of S. Section V reports the effect of $\mathrm{C}$ on the evaporation of $\mathrm{S}$ in the absence of 
Sn. Then, Section VI describes a comprehensive role of $\mathrm{C}$ on the evaporation of $\mathrm{Sn}$ and $\mathrm{S}$ simultaneously.

\section{EVAPORATION OF SN FROM LIQUID FE-C-SN ALLOY: ROLE OF C ON SN EVAPORATION}

The evaporation of $\mathrm{Sn}$ from liquid iron was investigated to clarify the effect of $\mathrm{C}$. As there was no $\mathrm{S}$ in the alloy, it was assumed that $\mathrm{Sn}$ evaporates solely as $\mathrm{Sn}(\mathrm{g})$. Figure 3 shows a decrease of [pct $\mathrm{Sn}$ ] in $\mathrm{Fe}-\mathrm{C}-\mathrm{Sn}$ alloy where [pct $\mathrm{C}]_{0}$ was 5.11 . To identify the effect of $\mathrm{C}$ on the evaporation of $\mathrm{Sn}(\mathrm{g})$, the previous experimental result for $\mathrm{Fe}-\mathrm{Sn}$ alloy without $\mathrm{C}$ was also compared. ${ }^{[15]}$ As shown in Figure 3, [pct $\mathrm{Sn}$ ] decreases considerably faster when the alloy contains $\mathrm{C}$.

The evaporation rate equation of $\mathrm{Sn}(\mathrm{g})$ from liquid iron is suggested as follows ${ }^{[15]}$ :

$$
\frac{d[\mathrm{pct} \mathrm{Sn}]}{d t}=-k_{\mathrm{Sn}} \frac{A}{V}[\mathrm{pct} \mathrm{Sn}]
$$

Integrating Eq. [3] yields:

$$
\ln \frac{[\text { pct } \mathrm{Sn}]}{[\text { pct Sn }]_{0}}=-k_{\mathrm{Sn}} \frac{A}{V} t
$$

and the apparent rate constant of the first-order rate equation $k_{\mathrm{Sn}}\left(\mathrm{m} \mathrm{s}^{-1}\right)$ may be expressed as:

$$
k_{\mathrm{Sn}}=\frac{k_{\mathrm{Sn}}^{\mathrm{R}}}{1+K_{\mathrm{S}} a_{\mathrm{S}}}
$$

where [pct $\mathrm{Sn}$ ], [pet $\mathrm{Sn}]_{0}, A, V, t, k_{\mathrm{Sn}}^{\mathrm{R}}$, and $K_{\mathrm{S}}$ are mass pet of $\mathrm{Sn}$ in the liquid alloy at time $t$, and at initial state $(t=0)$; the reaction area equal to the surface of the levitated droplet $\left(\mathrm{m}^{2}\right)$, the volume of the liquid alloy $\left(\mathrm{m}^{3}\right)$, the reaction time (seconds), the chemical reaction rate constant of Sn evaporation of Reaction [1] of fully open surface, $[$ pct $\mathrm{S}]=0,\left(\mathrm{~m} \mathrm{~s}^{-1}\right)$, and the adsorption

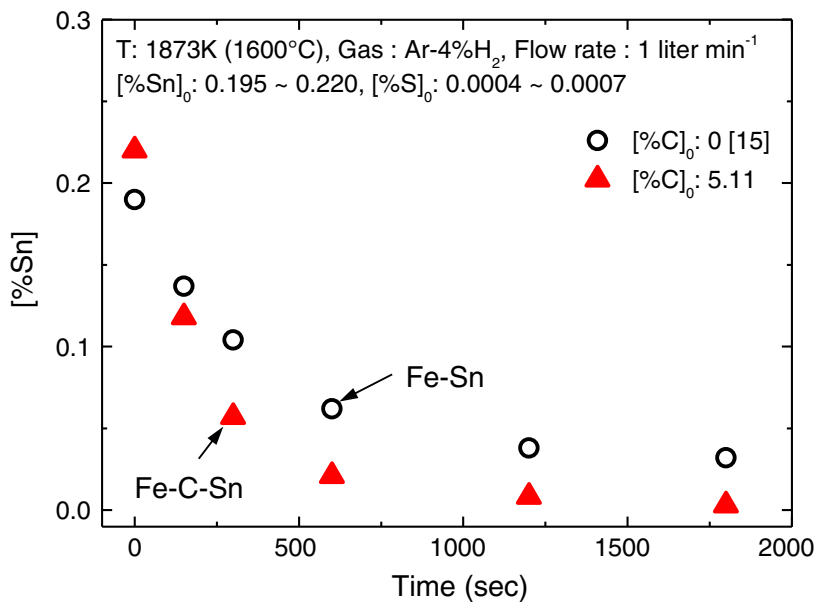

Fig. 3-Decrease of [pct $\mathrm{Sn}$ ] in the Fe-Sn alloy and the Fe-C-Sn $\left([\text { pct } \mathrm{C}]_{0}=5.11\right)$ alloy at $1873 \mathrm{~K}\left(1600{ }^{\circ} \mathrm{C}\right)$, [pct S $]_{0}: 0.004-0.0007$, and flow rate $=1 \mathrm{~L} \mathrm{~min}^{-1}$. coefficient for $\mathrm{S}$ in liquid iron, respectively. As the samples contained almost no $\mathrm{S}$ ([pct $\mathrm{S}]_{0}=0.0004$ $\sim 0.0007), k_{\mathrm{Sn}}$ may be set equal to $k_{\mathrm{Sn}}^{\mathrm{R}}$.

The experimental data were plotted according to Eq. [4] and are shown in Figure 4. $k_{\mathrm{Sn}}^{\mathrm{R}}$ was obtained as $3.49 \times 10^{-7}$ and $1.20 \times 10^{-6} \mathrm{~m} \mathrm{~s}^{-1}$ for the Fe-Sn alloy ${ }^{[15]}$ and the Fe-C-Sn alloy, respectively, at $1873 \mathrm{~K}\left(1600{ }^{\circ} \mathrm{C}\right)$.

As shown previously, ${ }^{[14,15]}$ the present experimental condition corresponded to a condition that a chemical reaction at the surface mainly controls the reaction rate of Reaction [1]. Therefore, the driving force of the evaporation reaction is dependent on the activity of reactant, Sn. It may be roughly assumed that $k_{\mathrm{Sn}}^{\mathrm{R}}$ and the activity coefficient of $\mathrm{Sn}, f_{\mathrm{Sn}}$, have the following relationship:

$$
k_{\mathrm{Sn}}^{\mathrm{R}}=k_{\mathrm{Sn}}^{\mathrm{R}, o} \frac{f_{\mathrm{Sn}}}{f_{\mathrm{Sn}}^{\mathrm{o}}}
$$

where $k_{\mathrm{Sn}}^{\mathrm{R}, \circ}$ and $f^{\circ} \mathrm{Sn}$ are the rate constant of $\mathrm{Sn}$ evaporation (Reaction [1]) of Fe-Sn alloy $\left(\mathrm{m} \mathrm{s}^{-1}\right)$ and the activity coefficient of $\mathrm{Sn}$ in Fe-Sn alloy, both without $\mathrm{C}$, respectively. $f^{\circ}$ Sn of the $\mathrm{Fe}-\mathrm{Sn}$ alloy and $f_{\mathrm{Sn}}$ of the $\mathrm{C}$ saturated liquid $\mathrm{Fe}-\mathrm{C}-\mathrm{Sn}$ alloy were reported as $2.8^{[16]}$ and $10.6,{ }^{[17]}$ respectively, at $1873 \mathrm{~K}\left(1600{ }^{\circ} \mathrm{C}\right)$.

As a ratio of $k_{\mathrm{Sn}}^{\mathrm{R}} / k_{\mathrm{Sn}}^{\mathrm{R}, \mathrm{o}}$ is 3.5 and a ratio of $f_{\mathrm{Sn}} / f^{\circ} \mathrm{Sn}$ is estimated to be 3.7 , the role of $\mathrm{C}$ on $\mathrm{Sn}(\mathrm{g})$ evaporation rate is likely to be attributed to the fact that $\mathrm{C}$ increases the activity coefficient of Sn.

\section{EVAPORATION OF S FROM LIQUID FE-C-S ALLOY: ROLE OF C AND EVAPORATION MECHANISM}

As preliminarily described in Section III, it is necessary to clarify whether there is a probable gas species containing $\mathrm{S}$ other than $\mathrm{SnS}(\mathrm{g})$ in the presence of $\mathrm{C}$ in liquid alloy to clearly elucidate the evaporation mechanism of Sn from liquid Fe-C-S-Sn alloy. Therefore, in the present study, the evaporation of $\mathrm{S}$ from Fe-C-S liquid alloys at $1873 \mathrm{~K}\left(1600{ }^{\circ} \mathrm{C}\right)$ was investigated as a separate study.

Figure 5 shows the change of [pct $\mathrm{S}$ ] in $\mathrm{Fe}(-\mathrm{C})-\mathrm{S}$ alloys ([pct $\mathrm{C}]_{0}=0$ or 4.85$)$ at $1873 \mathrm{~K}\left(1600{ }^{\circ} \mathrm{C}\right)$ under various flow rates of Ar-4 pct $\mathrm{H}_{2}$ gas in the reaction chamber. It is interesting to note that the decrease of [pct S] in the case of a C-containing alloy is seen to be significant, whereas that in the absence of $\mathrm{C}$ was almost negligible. From the results shown in Figure 5, it is thought that (1) $\mathrm{C}$ plays a significant role for evaporation of $\mathrm{S}$ from the liquid alloy, (2) S did not evaporate by itself without the help of $\mathrm{C}$, and (3) $\mathrm{H}$ in the gas introduced into the chamber did not take the $\mathrm{S}$ out of the liquid alloy. Therefore, the experimental data were further analyzed in the light of the role of $\mathrm{C}$. The evaporation rate of $\mathrm{S}$ may be formulated as:

$$
\frac{d[\text { pct } \mathrm{S}]}{d t}=-k_{\mathrm{S}} \frac{A}{V}[\mathrm{pct} \mathrm{S}]
$$

where $k_{\mathrm{S}}$ is an apparent rate constant $\left(\mathrm{m} \mathrm{s}^{-1}\right)$. Figure 6 shows the $k_{\mathrm{S}}$ extracted from the experimental data for 


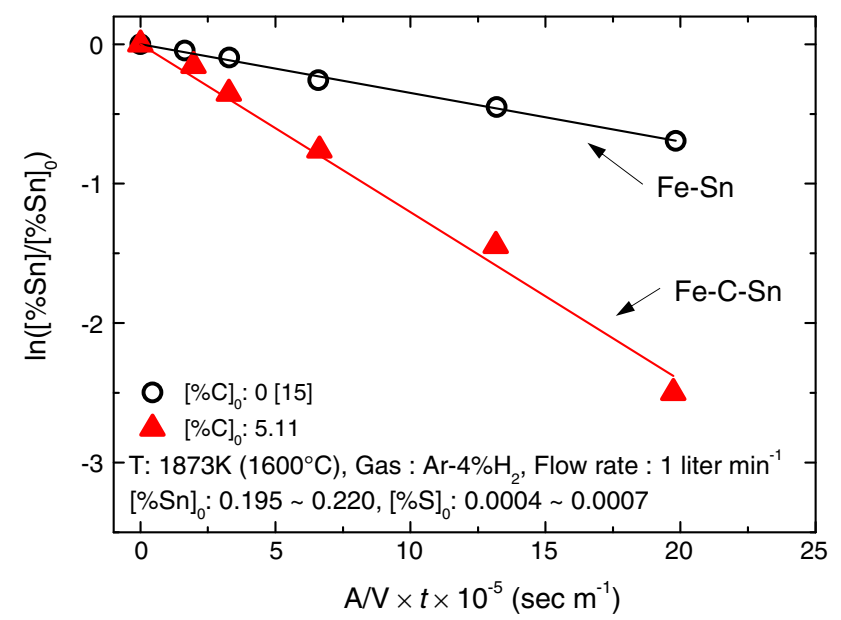

Fig. 4-Representation of the first-order rate equation of Eq. [4] for the alloys (Fe-Sn and Fe-C-Sn) shown in Fig. 3.

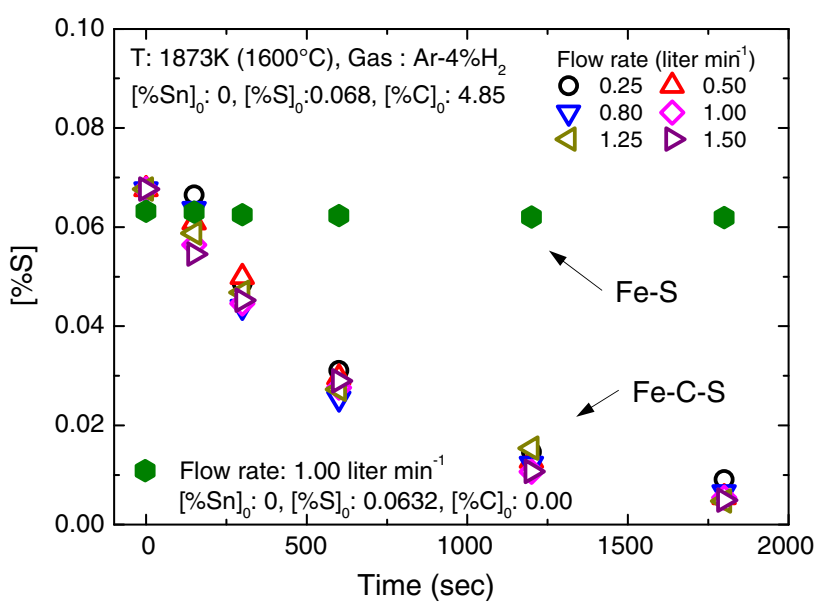

Fig. 5-Decrease of [pct S] in the Fe-S alloy and the Fe-C-S alloy under various gas flow rates at $1873 \mathrm{~K}\left(1600{ }^{\circ} \mathrm{C}\right)$.

the Fe-C-S alloys in Figure 5 at each flow rate. As can be seen in the figure, the $\mathrm{S}$ evaporation rate did not change when the flow rate was higher than $1 \mathrm{~L} \mathrm{~min}^{-1}$. Therefore, the effect of gas phase mass transfer could be neglected over $1 \mathrm{~L} \mathrm{~min}{ }^{-1}$ of flow rate, and further experiments was conducted at $1 \mathrm{~L} \mathrm{~min}^{-1}$ of the flow rate. Assuming liquid phase mass transfer was fast under the condition employed in the present study (relatively high solute concentrations of $\mathrm{C}$ and $\mathrm{S}$, and vigorously mixing condition in the electromagnetically levitated droplet), a chemical reaction on the surface would be rate determining step for evaporation reaction in the $\mathrm{Fe}-\mathrm{C}-\mathrm{S}$ liquid alloys.

From the experimental data shown in Figure $5, k_{\mathrm{S}}$ for the Fe-S alloy ([pet $\mathrm{C}_{0}$ : 0) and the Fe-C-S alloy ([pct $\mathrm{C}]_{0}: 4.85$, [pct $\left.\mathrm{S}\right]_{0}: 0.068$ ) at $1 \mathrm{~L} \mathrm{~min}^{-1}$ of flow rate were determined to be $1.27 \times 10^{-8} \mathrm{~m} \mathrm{~s}^{-1}$ and $1.31 \times 10^{-6} \mathrm{~m} \mathrm{~s}$ 1 , respectively. The $k_{\mathrm{S}}$ for the $\mathrm{Fe}-\mathrm{C}-\mathrm{S}$ alloy is approximately 100 times higher than the $\mathrm{k}_{\mathrm{S}}$ for the $\mathrm{Fe}-\mathrm{S}$ alloy. This difference cannot be only attributed to the increase of activity of $\mathrm{S}$ by the $\mathrm{C}$, because the activity coefficient of $\mathrm{S}$ is increased due to $\mathrm{C}$ as:

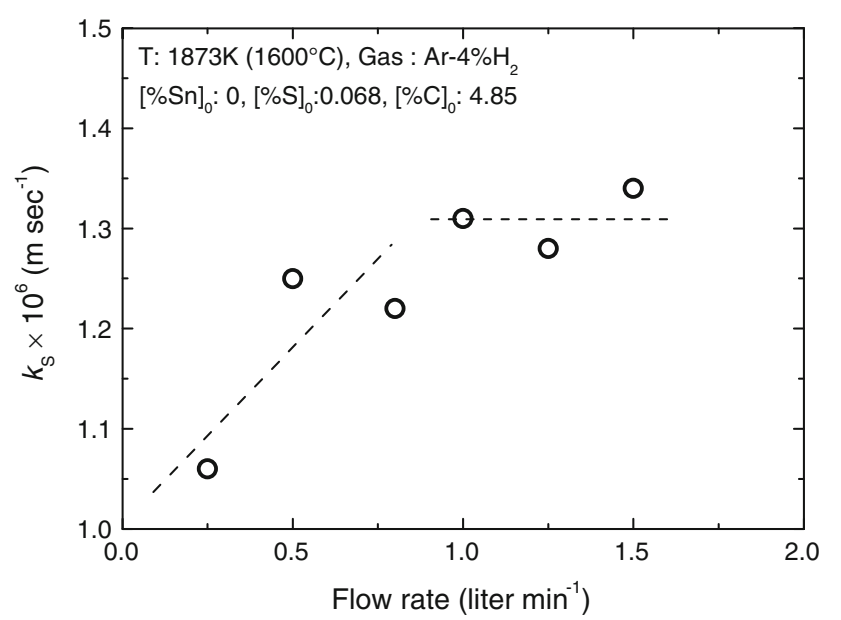

Fig. 6-The apparent first order rate constant $k_{\mathrm{S}}$ extracted from Fig. 5 at different flow rates.

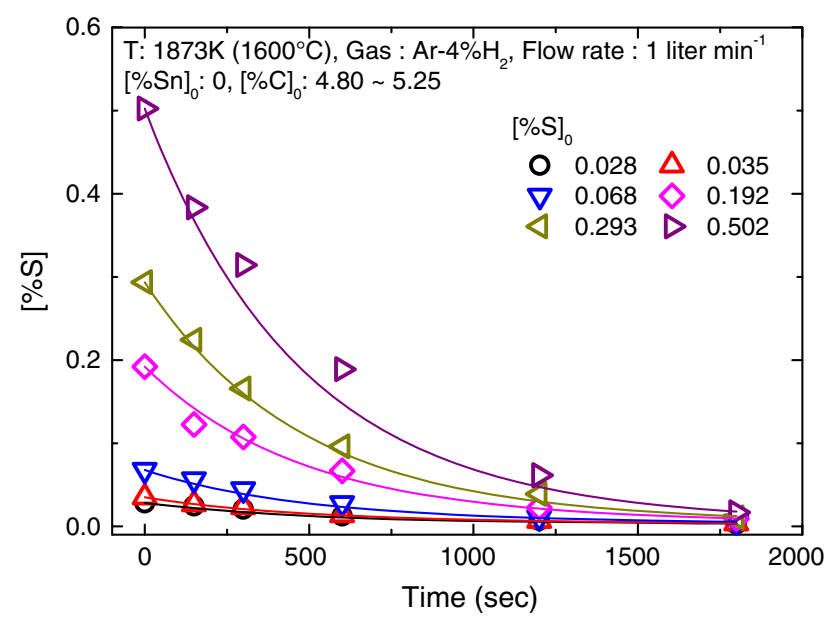

Fig. 7-Decrease of [pct S] in the Fe-C-S alloys of various [pct $\mathrm{S}]_{0}$ at $1873 \mathrm{~K}\left(1600{ }^{\circ} \mathrm{C}\right)$. [pet C] 0 : 4.80-5.25, flow rate: $1 \mathrm{~L} \mathrm{~min}^{-1}$, respectively. Lines are the calculation results of Eq. [16].

$$
\log f_{\mathrm{S}}=\log f_{\mathrm{S}}^{\circ}+e_{\mathrm{S}}^{\mathrm{C}}[\mathrm{pct} \mathrm{C}]
$$

where $e_{\mathrm{S}}^{\mathrm{C}}$ is the interaction parameter of $\mathrm{C}$ for $\mathrm{S}$ $\left(0.111\right.$ at $\left.1873 \mathrm{~K}\left(1600{ }^{\circ} \mathrm{C}\right)^{[18]}\right)$, and $f^{\circ} \mathrm{S}$ is the activity coefficient of $\mathrm{S}$ for $\mathrm{Fe}-\mathrm{S}$ alloy. This gives an only 3.5 times increase of $f^{\circ} \mathrm{S}$ for Fe-C-S by the C. Therefore, any gas species solely composed of $\mathrm{S}$ would not be the main evaporation gas species for the evaporation of $\mathrm{S}$ in the Fe-C-S alloy. This finding implies that some carbosulfide gas species should have been a major gas species for the evaporation.

Figure 7 shows a change of [pet S] in various Fe-C-S alloys with different [pct $\mathrm{S}]_{0}$ at high $\mathrm{C}$ contents ([pct $\left.\mathrm{C}\right]_{0}$ $=4.80$ to 5.25). Most of the probable carbosulfide gas species are $\mathrm{CS}(\mathrm{g})$ and $\mathrm{CS}_{2}(\mathrm{~g})$ according to the JANAF table ${ }^{[19]}$ and it is necessary to analyze which gas species would be appropriate to be considered.

Assuming the following Reaction [9] is a rate-controlling step for the evaporation of S: 


$$
\mathrm{C}^{i}+\mathrm{S}^{i}=\mathrm{CS}^{i}(\mathrm{~g})
$$

a second-order rate equation for $\mathrm{CS}(\mathrm{g})$ evaporation can be expressed as:

$$
\frac{d[\text { pct } \mathrm{S}]}{d t}=-k_{\mathrm{CS}} \frac{A}{V}[\text { pct } \mathrm{C}][\text { pct } \mathrm{S}]
$$

where $k_{\mathrm{CS}}$ is the apparent reaction rate constant for $\mathrm{CS}(\mathrm{g})$ evaporation $\left(\mathrm{m} \mathrm{s}^{-1}\right)$.

In the present authors' previous study, an ideal Langmuir isotherm and residual rate have been successfully applied to express the apparent reaction rate constant for the reaction: $\mathrm{Sn}+\mathrm{S}=\mathrm{SnS}(\mathrm{g}) .^{[14,15]}$ Therefore, based on the assumption that the rate constant for $\mathrm{CS}(\mathrm{g})$ evaporation also follows a similar relationship to that of $\mathrm{SnS}(\mathrm{g})$ evaporation, ${ }^{[15]} k_{\mathrm{CS}}$ was expressed as:

$$
k_{\mathrm{CS}}=\frac{\rho}{100 \mathrm{M}_{\mathrm{C}}}\left(\frac{k_{\mathrm{CS}}^{\mathrm{R}}}{1+K_{\mathrm{S}} f_{\mathrm{S}} / f_{\mathrm{S}}^{\mathrm{o}}[\text { pct S}]}+k_{\mathrm{CS}}^{\mathrm{r}}\right)
$$

where $k_{\mathrm{CS}}^{\mathrm{R}}, k_{\mathrm{CS}}^{\mathrm{r}}, \rho$, and $\mathrm{M}_{\mathrm{C}}$ are a chemical reaction rate constant of CS(g) evaporation of fully open surface $\left(\mathrm{m}^{4} \mathrm{~mol}^{-1} \mathrm{~s}^{-1}\right)$, the residual rate constant for the CS $(\mathrm{g})$ evaporation $\left(\mathrm{m}^{4} \mathrm{~mol}^{-1} \mathrm{~s}^{-1}\right)$, the density of liquid alloy $\left(\mathrm{kg} \mathrm{m}^{-3}\right)$, and the molecular weight of $\mathrm{C}\left(\mathrm{kg} \mathrm{mol}^{-1}\right)$, respectively. The adsorption coefficient for $\mathrm{S}, K_{\mathrm{S}}=40$, was taken from Reference 20 , and $f_{\mathrm{S}} / f^{\circ} \mathrm{S}$ was set to 3.5 in order to consider the effect of $\mathrm{C}$ on the activity coefficient of S. ${ }^{[21]}$ Inserting Eq. [11] into Eq. [10] and integrating the equation, assuming $\Delta n_{\mathrm{S}}=\Delta n_{\mathrm{C}}$, gives:

$$
\begin{aligned}
& \frac{1}{\alpha_{\mathrm{CS}}\left(1+\varepsilon_{\mathrm{CS}}\right)} \ln \frac{[\mathrm{pct} \mathrm{S}]}{[\mathrm{pct} \mathrm{S}]_{0}} \\
& +\frac{K_{\mathrm{S}}\left(f_{\mathrm{S}} / f_{\mathrm{S}}^{\circ}\right) \alpha_{\mathrm{CS}}-\beta_{\mathrm{CS}}}{\alpha_{\mathrm{CS}}\left(\beta_{\mathrm{CS}}\left(1+\varepsilon_{\mathrm{CS}}\right)-\alpha_{\mathrm{CS}} \varepsilon_{\mathrm{CS}} K_{\mathrm{S}}\left(f_{\mathrm{S}} / f_{\mathrm{S}}^{\circ}\right)\right)} \\
& \times \ln \frac{\alpha_{\mathrm{CS}}+\beta_{\mathrm{CS}}[\mathrm{pct} \mathrm{S}]}{\alpha_{\mathrm{CS}}+\beta_{\mathrm{CS}}[\mathrm{pct} \mathrm{S}]_{0}} \\
& -\frac{\varepsilon_{\mathrm{CS}}\left(K_{\mathrm{S}}\left(f_{\mathrm{S}} / f_{\mathrm{S}}^{\circ}\right)\right)^{2}}{\left(\beta_{\mathrm{CS}}\left(1+\varepsilon_{\mathrm{CS}}\right)-\alpha_{\mathrm{CS}} \varepsilon_{\mathrm{CS}} K_{\mathrm{S}}\left(f_{\mathrm{S}} / f_{\mathrm{S}}^{\circ}\right)\right)\left(1+\varepsilon_{\mathrm{CS}}\right)} \\
& \times \ln \frac{1+\varepsilon_{\mathrm{CS}}+\varepsilon_{\mathrm{CS}} K_{\mathrm{S}}\left(f_{\mathrm{S}} / f_{\mathrm{S}}^{\circ}\right)[\mathrm{pct} \mathrm{S}]}{1+\varepsilon_{\mathrm{CS}}+\varepsilon_{\mathrm{CS}} K_{\mathrm{S}}\left(f_{\mathrm{S}} / f_{\mathrm{S}}^{\circ}\right)[\mathrm{pct} \mathrm{S}]_{0}} \\
& =-\frac{\rho k_{\mathrm{CS}}^{\mathrm{R}}}{100 \mathrm{M}_{\mathrm{C}}} \frac{A}{V} t
\end{aligned}
$$

where

$$
\begin{gathered}
\alpha_{\mathrm{CS}}:[\text { pct } \mathrm{C}]_{0}-\mathrm{M}_{\mathrm{C}} / \mathrm{M}_{\mathrm{S}}[\text { pct } \mathrm{S}]_{0} \\
\beta_{\mathrm{CS}}: \mathrm{M}_{\mathrm{C}} / \mathrm{M}_{\mathrm{S}} \\
\varepsilon_{\mathrm{CS}}: k_{\mathrm{CS}}^{\mathrm{r}} / k_{\mathrm{CS}}^{\mathrm{R}}
\end{gathered}
$$

respectively. The left-hand side (LHS) of Eq. [12] as a function of time $t$ should show a linear relation with a constant slope regardless of [pct S], if the CS(g) is the major evaporating gas species in Fe-C-S alloy. In Figure 8, the experimental data from Figure 7 were plotted using Eq. [12]. The vertical axis of Figure 8 represents the LHS of Eq. [12]. The result shows linearity between the LHS and $t$, but $k_{\mathrm{CS}}^{\mathrm{R}}$, which can be obtained from the slope of the linear plots, is seen to increase as $[\mathrm{pct} \mathrm{S}]_{0}$ increases from 0.028 to 0.502 . This finding does not support the assumption that $\mathrm{CS}(\mathrm{g})$ would be a major evaporating gas species.

Because $k_{\mathrm{CS}}^{\mathrm{R}}$ is proportional to [pet $\left.\mathrm{S}\right]_{0}$, it may be postulated that the evaporating gas species may contain more $\mathrm{S}$ than that in the $\mathrm{CS}(\mathrm{g})$. Therefore, the following reaction is considered as a rate-controlling step for evaporation of $\mathrm{S}$ assuming $\mathrm{CS}_{2}(\mathrm{~g})$ is the major evaporating gas species:

$$
\mathrm{C}^{i}+2 \mathrm{~S}^{i}=\mathrm{CS}_{2}^{i}(\mathrm{~g})
$$

The corresponding rate equation for the decrease of $\mathrm{S}$ may be expressed as:

$$
\frac{d[\mathrm{pct} \mathrm{S}]}{d t}=-k_{\mathrm{CS}_{2}} \frac{A}{V}[\text { pct } \mathrm{C}][\text { pct } \mathrm{S}]^{2}
$$

where $k_{\mathrm{CS}_{2}}$ is the apparent reaction rate constant for $\mathrm{CS}_{2}(\mathrm{~g})$ evaporation $\left(\mathrm{m} \mathrm{s}^{-1}\right)$.

Assuming the ideal Langmuir isotherm and the possibility of existence of residual rate for $\mathrm{CS}_{2}(\mathrm{~g})$ evaporation, $k_{\mathrm{CS}_{2}}^{\mathrm{R}}$ is expressed as:

$$
k_{\mathrm{CS}_{2}}=\frac{\rho^{2}}{10000 \mathrm{M}_{\mathrm{C}} \mathrm{M}_{\mathrm{S}}}\left(\frac{k_{\mathrm{CS}_{2}}^{\mathrm{R}}}{1+K_{\mathrm{S}} f_{\mathrm{S}} / f_{\mathrm{S}}^{\mathrm{\rho}}[\mathrm{pct} \mathrm{S}]}+k_{\mathrm{CS}_{2}}^{\mathrm{r}}\right)
$$

where $k_{\mathrm{CS}_{2}}^{\mathrm{R}}$ and $k_{\mathrm{CS} 2}^{\mathrm{r}}$ are the chemical reaction rate constant of $\mathrm{CS}_{2}(\mathrm{~g})$ evaporation of fully open surface $\left(\mathrm{m}^{7} \mathrm{~mol}^{-2} \mathrm{~s}^{-1}\right)$ and the residual rate constant of $\mathrm{CS}_{2}(\mathrm{~g})$ evaporation $\left(\mathrm{m}^{7} \mathrm{~mol}^{-2} \mathrm{~s}^{-1}\right)$, respectively. Inserting Eq. [15] into Eq. [14] and integrating the equation, assuming $\Delta n_{\mathrm{S}}=2 \Delta n_{\mathrm{C}}$, gives:

$$
\begin{aligned}
& \frac{1-\alpha_{\mathrm{CS}_{2}} \varepsilon_{\mathrm{CS}_{2}} K_{\mathrm{S}}\left(f_{\mathrm{S}} / f_{\mathrm{S}}^{\circ}\right)}{\alpha_{\mathrm{CS} 2} \beta_{\mathrm{CS}_{2}}\left(1-\alpha_{\mathrm{CS}_{2}} \varepsilon_{\mathrm{CS}_{2}} K_{\mathrm{S}}\left(f_{\mathrm{S}} / f_{\mathrm{S}}^{\circ}\right)\right)\left(1+\varepsilon_{\mathrm{CS}}\right)} \\
& \times\left(\frac{1}{[\mathrm{pctS}]_{0}}-\frac{1}{[\mathrm{pctS}]}\right) \\
& +\frac{\left(\alpha_{\mathrm{CS} 2} K_{\mathrm{S}}\left(f_{\mathrm{S}} / f_{\mathrm{S}}^{\circ}\right)-1\right)\left(1+\varepsilon_{\mathrm{CS} 2}\right)^{2}-\varepsilon_{\mathrm{CS} 2}\left(\alpha_{\mathrm{CS} 2} K_{\mathrm{S}}\left(f_{\mathrm{S}} / f_{\mathrm{S}}^{\circ}\right)\right)^{2}}{\left(\alpha_{\mathrm{CS} 2}\right)^{2} \beta_{\mathrm{CS} 2}\left(1-\alpha_{\mathrm{CS} 2} \varepsilon_{\mathrm{CS} 2} K_{\mathrm{S}}\left(f_{\mathrm{S}} / f_{\mathrm{S}}^{\circ}\right)\right)\left(1+\varepsilon_{\mathrm{CS} 2}\right)^{2}} \\
& \times \ln \frac{[\mathrm{pct} \mathrm{S}]}{[\mathrm{pct}]_{0}}+\frac{1-\alpha_{\mathrm{CS}} K_{\mathrm{S}}\left(f_{\mathrm{S}} / f_{\mathrm{S}}^{\circ}\right)}{\left(\alpha_{\mathrm{CS}}\right)^{2} \beta_{\mathrm{CS}_{2}}\left(1-\alpha_{\mathrm{CS}_{2}} \varepsilon_{\mathrm{CS}} K_{\mathrm{S}}\left(f_{\mathrm{S}} / f_{\mathrm{S}}^{\circ}\right)\right)} \\
& \times \ln \frac{\alpha_{\mathrm{CS}_{2}}+[\mathrm{pctS}]}{\alpha_{\mathrm{CS}_{2}}+[\mathrm{pct}]_{0}}+\frac{\left(\varepsilon_{\mathrm{CS}_{2}}\right)^{2}\left(K_{\mathrm{S}}\left(f_{\mathrm{S}} / f_{\mathrm{S}}^{\circ}\right)\right)^{3}}{\beta_{\mathrm{CS}_{2}}\left(1-\alpha_{\mathrm{CS}_{2}} \varepsilon_{\mathrm{CS}_{2}} K_{\mathrm{S}}\left(f_{\mathrm{S}} / f_{\mathrm{S}}^{\circ}\right)\right)\left(1+\varepsilon_{\mathrm{CS}_{2}}\right)^{2}} \\
& \times \ln \frac{1+\varepsilon_{\mathrm{CS}_{2}}+\varepsilon_{\mathrm{CS}_{2}} K_{\mathrm{S}}\left(f_{\mathrm{S}} / f_{\mathrm{S}}^{\circ}\right)[\mathrm{pct} \mathrm{S}]}{1+\varepsilon_{\mathrm{CS}_{2}}+\varepsilon_{\mathrm{CS}_{2}} K_{\mathrm{S}}\left(f_{\mathrm{S}} / f_{\mathrm{S}}^{\circ}\right)[\mathrm{pct}]_{0}}=-\frac{\rho^{2} k_{\mathrm{CS}_{2}}^{\mathrm{R}}}{10000 \mathrm{M}_{\mathrm{C}} \mathrm{M}_{\mathrm{S}}} \frac{A}{V} t
\end{aligned}
$$

where

$$
\begin{gathered}
\alpha_{\mathrm{CS}_{2}}: 2 \mathrm{M}_{\mathrm{S}} / \mathrm{M}_{\mathrm{C}}[\text { pct } \mathrm{C}]_{0}-[\text { pct } \mathrm{S}]_{0} \\
\beta_{\mathrm{CS}_{2}}: \mathrm{M}_{\mathrm{C}} / 2 \mathrm{M}_{\mathrm{S}}
\end{gathered}
$$




$$
\varepsilon_{\mathrm{CS}_{2}}: k_{\mathrm{CS}_{2}}^{\mathrm{r}} / k_{\mathrm{CS}_{2}}^{\mathrm{R}}
$$

respectively. In Figure 9, the experimental data from Figure 7 were plotted using Eq. [16]. The vertical axis of Figure 9 represents the LHS of Eq. [16]. A good linear relationship was obtained with 0.0001 of $\varepsilon_{\mathrm{CS}_{2}}$. From the slope of the plot, $k_{\mathrm{CS}_{2}}^{\mathrm{R}}$ was obtained as $4.24 \times 10^{-12}$ $\mathrm{m}^{7} \mathrm{~mol}^{-2} \mathrm{~s}^{-1}$ and the corresponding $k_{\mathrm{CS}_{2}}^{\mathrm{r}}$ was $4.24 \times 10^{-16}$ $\mathrm{m}^{7} \mathrm{~mol}^{-2} \mathrm{~s}^{-1}$.Using the obtained $k_{\mathrm{CS}_{2}}^{\mathrm{R}}$ and $k_{\mathrm{CS}_{2}}^{\mathrm{r}}$ along with Eq. [16], which has been derived from Eq. [14] assuming that $\mathrm{CS}_{2}(\mathrm{~g})$ was the major evaporation gas species. [pct $\mathrm{S}$ ] in the several $\mathrm{Fe}-\mathrm{C}-\mathrm{S}$ alloys was back calculated and is shown in Figure 7 by solid lines. It shows a good agreement with the experimental results of various initial $\mathrm{S}$ contents. This lends strong support to the assumption made in this analysis that the $\mathrm{CS}_{2}(\mathrm{~g})$ is the major evaporation gas species in the Fe-C-S liquid alloy.

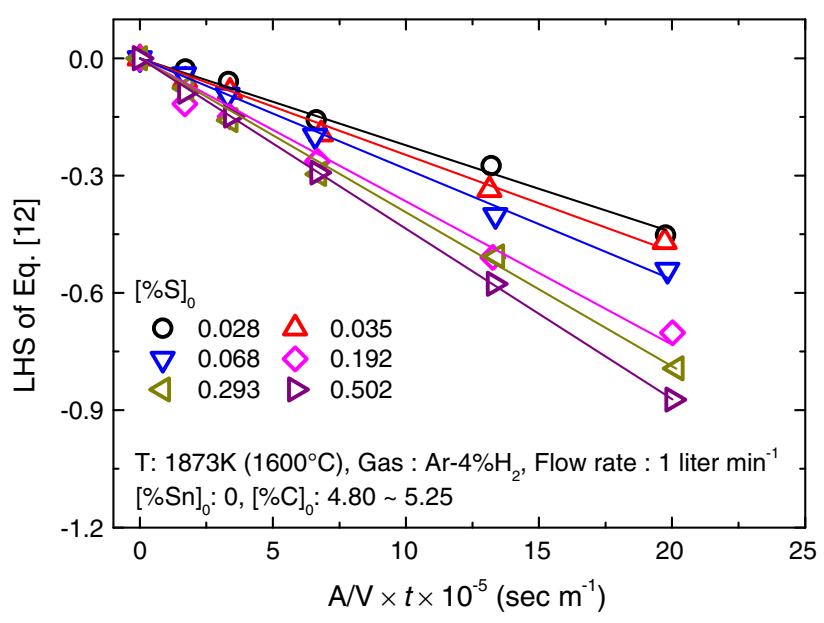

Fig. 8-Representation of the second-order rate equation of Eq. [12] for the evaporation of $\mathrm{S}$ assuming $\mathrm{CS}(\mathrm{g})$ as a evaporating gas species. Adsorption of $\mathrm{S}$ and the residual sites are both considered.

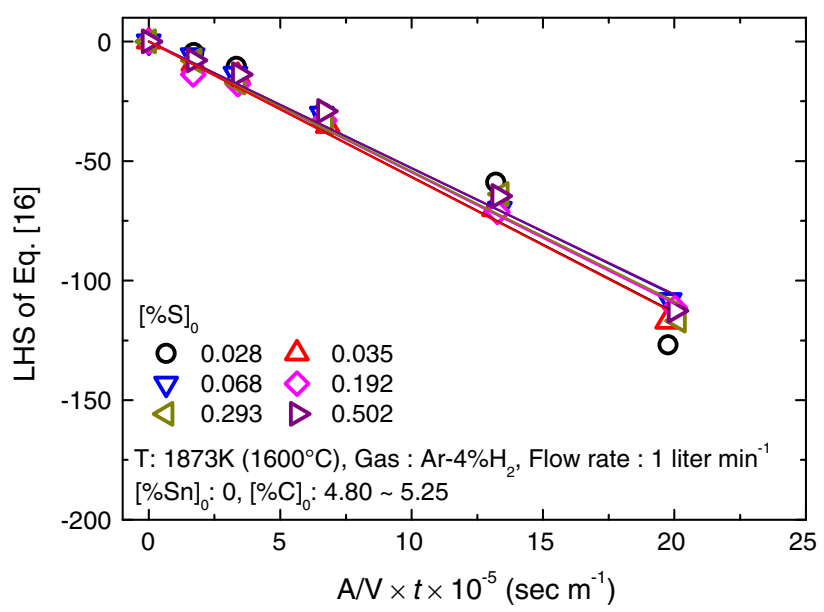

Fig. 9-Representation of the third-order rate equation of Eq. [16] for the evaporation of $\mathrm{S}$ assuming $\mathrm{CS}_{2}(\mathrm{~g})$ as a evaporating gas species. Adsorption of $\mathrm{S}$ and the residual sites are both considered.

\section{EVAPORATION OF SN FROM LIQUID FE-C-S-SN ALLOY}

From the previous analysis as well as those found in the previous investigations, ${ }^{[14,15]}$ it has been elucidated that $\mathrm{Sn}$ evaporates from liquid $\mathrm{Fe}-\mathrm{C}-\mathrm{Sn}-\mathrm{S}$ alloy in forms of $\mathrm{Sn}(\mathrm{g})$ and $\mathrm{SnS}(\mathrm{g})$, whereas $\mathrm{CS}_{2}(\mathrm{~g})$ also evaporates simultaneously. At the same time, $\mathrm{S}$ blocks the reaction sites that could be interpreted in the framework of Langmuir's ideal adsorption. ${ }^{[22]}$ These facts are schematically shown in Figure 10.

Taking into account of all these facts, evaporation of Sn from liquid Fe-C-Sn-S alloy was quantitatively predicted utilizing previously developed rate equations. Assuming evaporations of $\mathrm{Sn}(\mathrm{g}), \mathrm{SnS}(\mathrm{g})$, and $\mathrm{CS}_{2}(\mathrm{~g})$ are independent each other, the following rate equations are derived for $\mathrm{Sn}$ and $\mathrm{S}$, respectively:

$$
\begin{aligned}
\frac{d[\mathrm{pct} \mathrm{Sn}]}{d t}= & -\frac{A}{V}\left(k_{\mathrm{Sn}}\left(f_{\mathrm{Sn}} / f_{\mathrm{Sn}}^{\circ}\right)[\mathrm{pct} \mathrm{Sn}]\right. \\
& \left.+k_{\mathrm{SnS}}\left(f_{\mathrm{Sn}} / f_{\mathrm{Sn}}^{\circ}\right)\left(f_{\mathrm{S}} / f_{\mathrm{S}}^{\circ}\right)[\mathrm{pct} \mathrm{Sn}][\mathrm{pct} \mathrm{S}]\right) \\
\frac{d[\mathrm{pct} \mathrm{S}]}{d t}= & -\frac{A}{V}\left(\frac{\mathrm{M}_{\mathrm{S}}}{\mathrm{M}_{\mathrm{Sn}}} k_{\mathrm{SnS}}\left(f_{\mathrm{Sn}} / f_{\mathrm{Sn}}^{\circ}\right)\left(f_{\mathrm{S}} / f_{\mathrm{S}}^{\circ}\right)[\text { pct Sn }][\text { pct S }]\right. \\
+ & \left.k_{\mathrm{CS}_{2}}[\mathrm{pct} \mathrm{C}][\mathrm{pct} \mathrm{S}]^{2}\right) \\
k_{\mathrm{SnS}}= & \frac{\rho}{100 \mathrm{M}_{\mathrm{S}}}\left(\frac{k_{\mathrm{Sn}}^{\mathrm{R}}}{1+K_{\mathrm{S}}\left(f_{\mathrm{S}} / f_{\mathrm{S}}^{\circ}\right)[\mathrm{pct} \mathrm{S}]}+k_{\mathrm{SnS}}^{\mathrm{r}}\right)
\end{aligned}
$$

where $k_{\mathrm{SnS}}, k_{\mathrm{SnS}}^{\mathrm{R}}$, and $k_{\mathrm{SnS}}^{\mathrm{r}}$ are the apparent reaction rate constant for $\operatorname{SnS}(\mathrm{g})$ evaporation $\left(\mathrm{m} \mathrm{s}^{-1}\right)$, the chemical reaction rate constant of $\mathrm{SnS}(\mathrm{g})$ evaporation of fully open surface $\left(\mathrm{m}^{4} \mathrm{~mol}^{-1} \mathrm{~s}^{-1}\right)$, and the residual rate constant of $\mathrm{SnS}(\mathrm{g})$ evaporation $\left(\mathrm{m}^{4} \mathrm{~mol}^{-1} \mathrm{~s}^{-1}\right)$, respectively, as defined in Reference $15 . k_{\mathrm{Sn}}^{\mathrm{R}}, k_{\mathrm{SnS}}^{\mathrm{R}}$, and $k_{\mathrm{SnS}}^{\mathrm{r}}$ are reported as $3.49 \times 10^{-7} \mathrm{~m} \mathrm{~s}^{-1}, 1.0 \times 10^{-8} \mathrm{~m}^{4} \mathrm{~mol}^{-1} \mathrm{~s}^{-1}$, and $1.4 \times 10^{-9} \mathrm{~m}^{4} \mathrm{~mol}^{-1} \mathrm{~s}^{-1}$ at $1873 \mathrm{~K}\left(1600{ }^{\circ} \mathrm{C}\right)$, respectively. ${ }^{[15]}$ By calculating Eqs. [17] and [18] with

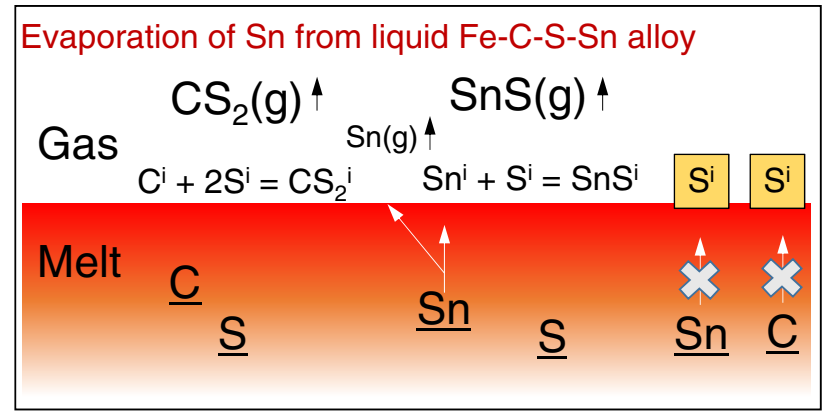

Fig. 10-A conceptual model for the evaporation of Sn, S, and C from a liquid Fe-C-S-Sn alloy. Surface adsorption of $\mathrm{S}$ is also described in boxes. 
evaporation rate constants of $\mathrm{Sn}(\mathrm{g}), \mathrm{SnS}(\mathrm{g})$, and $\mathrm{CS}_{2}(\mathrm{~g})$ from Eqs. [19], [20], and [15], it is possible to calculate the changes of [pct Sn] and [pct S] during the evaporation reaction of the Fe-C-S-Sn alloy. Also to validate the calculations for the evaporation in the Fe-C-Sn-S alloy, additional experiments were conducted for various [pct $\mathrm{S}]_{0}$.

Figures 11 and 12 show the changes of [pet Sn] and [pct S] in the Fe-C-S-Sn alloys at $1873 \mathrm{~K}\left(1600^{\circ} \mathrm{C}\right)$ for various [pet $\mathrm{S}]_{0}$. The experimental data are shown by symbols. As expected, both [pct Sn] and [pct S] decreased. The decrease of [pct Sn] was accelerated by the increase of [pct S $]_{0}$. Lines in these figures are the calculated results according to the model equations developed in the current study. Equations [17] and [18] were solved numerically with a short time step $(\Delta t=$ 5 seconds). The change of [pct $\mathrm{C}$ ] due to the evaporation of $\mathrm{CS}_{2}(\mathrm{~g})$ was also taken into account in the calculation,

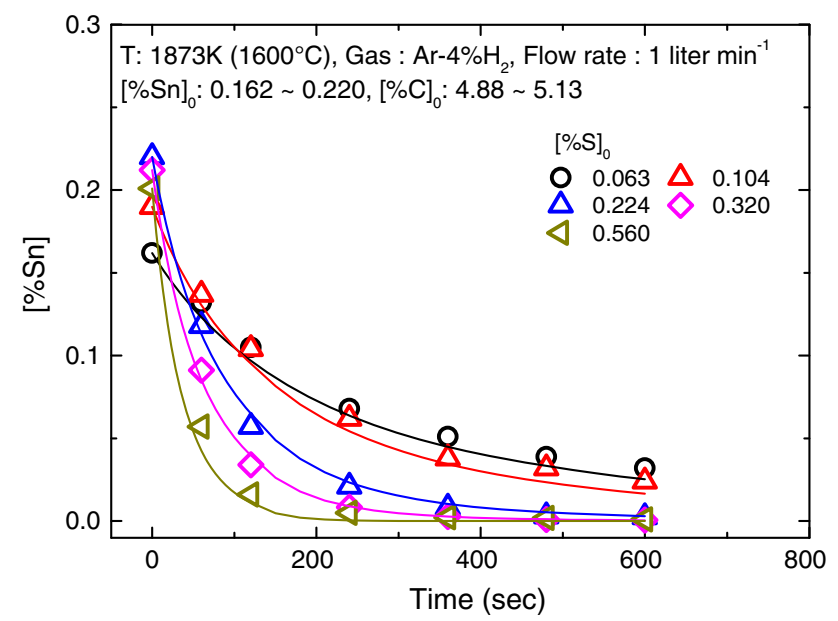

Fig. 11-Decrease of [pct Sn] in the Fe-C-S-Sn alloys of various [pct $\mathrm{S}]_{0}$ at $1873 \mathrm{~K}\left(1600{ }^{\circ} \mathrm{C}\right)$. [pct Sn] $]_{0}: 0.162-0.220$, [pct C] $]_{0}: 4.88-5.13$, flow rate: $1 \mathrm{~L} \mathrm{~min}^{-1}$, respectively. Lines are the calculation results of Eq. [17] coupled with Eq. [18].

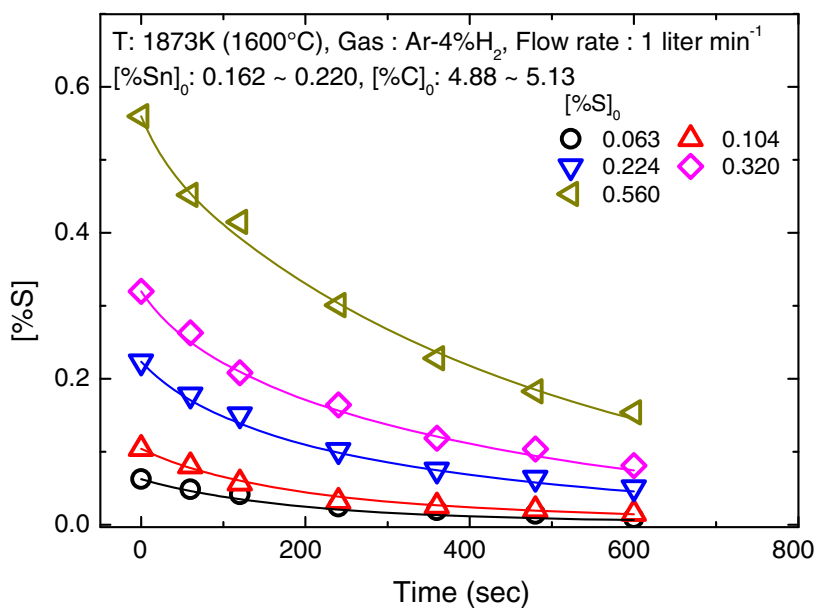

Fig. 12-Decrease of [pct S] in the Fe-C-S-Sn alloys shown in Fig. 11. [pct Sn] $]_{0}: 0.162-0.220$, [pct C] $]_{0}: 4.88-5.13$, flow rate: $1 \mathrm{~L}$ $\mathrm{min}^{-1}$, respectively. Lines are the calculation results of Eq. [18] coupled with Eq. [17]. except for its effect on $f_{\mathrm{S}}$ and $f_{\mathrm{Sn}}$. This was because the change of [pct $\mathrm{C}$ ] due to the evaporation is approximately $0.5 \times \Delta$ [pct $\mathrm{S}] \times \mathrm{M}_{\mathrm{C}} / \mathrm{M}_{\mathrm{S}}$, which is very small compared with the initial $\mathrm{C}$ content $[\mathrm{pct} \mathrm{C}]_{0}$. For example, $\Delta$ [pct S] $=0.4$ corresponds to $\Delta[$ pct $\mathrm{C}]=$ 0.075 , and this is only $1-2$ pct of the initial C content. This affects hardly the value of $f_{\mathrm{S}}$ and $f_{\mathrm{Sn}}$. Therefore, for the sake of simplicity, $f_{\mathrm{S}}$ and $f_{\mathrm{Sn}}$ were assumed to be constant during the calculations.

\section{APPLICATION OF THE EVAPORATION MODEL EQUATIONS: CHANGE OF EVAPORATION MODE AND PROCESS TIME FOR PRACTICAL APPLICATION}

Shown in Figure 2 by a curve is a calculated number of moles of $\mathrm{S}$ and $\mathrm{Sn}$ for a Fe-C-S-Sn alloy. As mentioned in Section III, the initial relationship $\left(\Delta n_{\mathrm{S}}\right.$ $\left.>\Delta n_{\mathrm{Sn}}\right)$ which was not observed in Fe-S-Sn alloys, ${ }^{[14,15]}$ is very well accounted for by the present model equation. The calculation is in good accordance with the experimental data. Moreover, the initial relationship $\left(\Delta n_{\mathrm{S}}>\Delta n_{\mathrm{Sn}}\right)$ gradually changes to an opposite relationship $\left(\Delta n_{\mathrm{S}}<\Delta n_{\mathrm{Sn}}\right)$. This seems to the change of evaporation mode from $\mathrm{SnS}(\mathrm{g})+\mathrm{CS}_{2}(\mathrm{~g})$ with minor $\mathrm{Sn}(\mathrm{g})$ to $\mathrm{SnS}(\mathrm{g})+\mathrm{Sn}(\mathrm{g})$ with minor $\mathrm{CS}_{2}(\mathrm{~g})$ as [pct $\mathrm{S}$ ] decreases in the alloy. Using the model equations developed in the present study, such a change of the evaporation mode was analyzed for an example case.

It is defined that $d[\mathrm{pct} \mathrm{Sn}]_{0} / d t$ is the initial evaporation rate of $\mathrm{Sn}$. The initial rate for $\mathrm{Sn}(\mathrm{g})$ and $\mathrm{SnS}(\mathrm{g})$, and the overall rate of Sn evaporation at $1873 \mathrm{~K}\left(1600{ }^{\circ} \mathrm{C}\right)$, were calculated and are shown in Figures 13(a) and (b), for Fe-S-Sn alloy (thin lines) and Fe-C-S-Sn alloy (thick lines). Figure 13(a) shows the overall evaporation rate of $\mathrm{Sn}$ for the Fe-S-Sn alloy and the Fe-C-S-Sn alloy. The rate for the $\mathrm{C}$ containing alloy is seen to be much higher, and the difference between two calculated rates becomes more significant with increasing $[p c t S]_{0}$. It can be interpreted that $\mathrm{C}$ increases activity coefficients of $\mathrm{Sn}$ and S simultaneously for Reactions [1] and [2], and the evaporation rate at high $[\mathrm{pct} \mathrm{S}]_{0}$ is more affected by the C through Reaction [2].

Figures 14(a) through (c) show the change of [pct Sn] and [pct S] during evaporation; the number of moles of evaporated $\mathrm{Sn}(\mathrm{g}), \mathrm{SnS}(\mathrm{g})$, and $\mathrm{CS}_{2}(\mathrm{~g})$; and the relative fractions of each gas species, respectively. From these figures, it can be seen that $\mathrm{SnS}(\mathrm{g})$ and $\mathrm{CS}_{2}(\mathrm{~g})$ are main evaporation gas species, and about 73 pct of S available contributes to the formation of $\mathrm{SnS}(\mathrm{g})$ at the beginning stage of evaporation. It means rest of $S(\sim 27 \mathrm{pct})$ is competitively consumed by the $\mathrm{C}$, and this is not used by Sn evaporation. At the later stage of the evaporation, the mode of evaporation changes that $\mathrm{Sn}(\mathrm{g})$ becomes a main evaporation gas species because [pct $\mathrm{S}$ ] in the liquid alloy has already been consumed.

One of the most important factors for a practical point of view is how fast the Sn evaporates from a liquid steel. It is strongly required to increase the evaporation rate as much as possible to be practically used in a scrap 


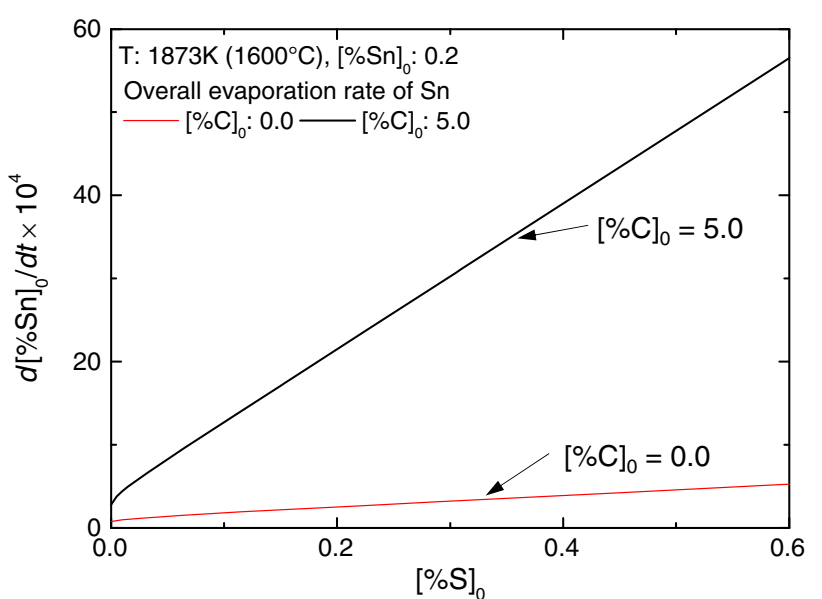

(a)

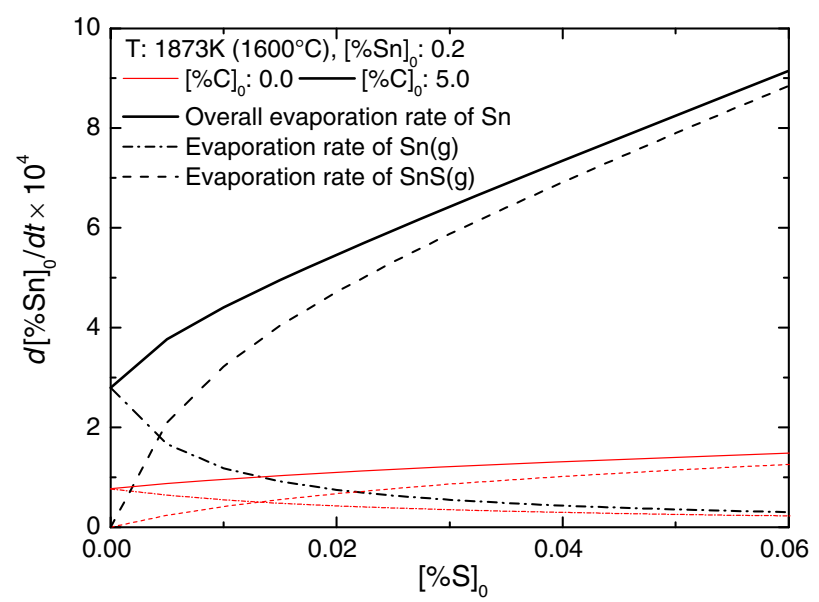

(b)

Fig. 13 - Calculated initial evaporation rate of $\mathrm{Sn}, d[\mathrm{pct} \mathrm{Sn}]_{0} / d t$, at $1873 \mathrm{~K}\left(1600{ }^{\circ} \mathrm{C}\right)$. The evaporation rate in forms of $\mathrm{Sn}(\mathrm{g})$ and $\mathrm{SnS}(\mathrm{g})$ as well as the overall evaporation rate are shown for low [pct $\mathrm{S}]_{0}$ region $(b)$.

refining process. Therefore, it is useful to seek an optimal condition for the Sn removal. One of routes for the optimum condition is to find an optimal $\mathrm{S}$ content that results in a faster evaporation rate of $\mathrm{Sn}$, and this may be investigated by using the comprehensive evaporation rate equation developed in the current study. The existence of $\mathrm{S}$ causes an increase of $\mathrm{Sn}$ removal rate, while the final $\mathrm{S}$ content should be lower than a $\mathrm{S}$ content that can be removed by usual desulfurization process in a steelmaking process. Therefore, it was attempted to find an optimal initial $\mathrm{S}$ content under the condition that initial $\mathrm{Sn}$ content $[\mathrm{pct} \mathrm{Sn}]_{0}$ is 0.2 , and final $\mathrm{S}$ content [pct $\mathrm{S}]_{\mathrm{f}}$ is 0.06 after 50 pct of detinning ([pct $\left.\mathrm{Sn}]_{\mathrm{f}}=0.1\right)$. Other conditions such as reaction temperature, mass transport in liquid and gas are assumed to be identical to those employed in the present experimental study. A series of calculations using the model as shown in Figure 15 revealed that 0.103 of [pct $S]_{0}$ is the optimal value for $\mathrm{C}$ saturated liquid $\mathrm{Fe}$ alloy, for which [pct $\mathrm{S}]_{\mathrm{f}}$ is 0.06 after 50 pet of detinning (from 0.2 to 0.1 for [pct Sn]). The time required for the 50 pct detinning

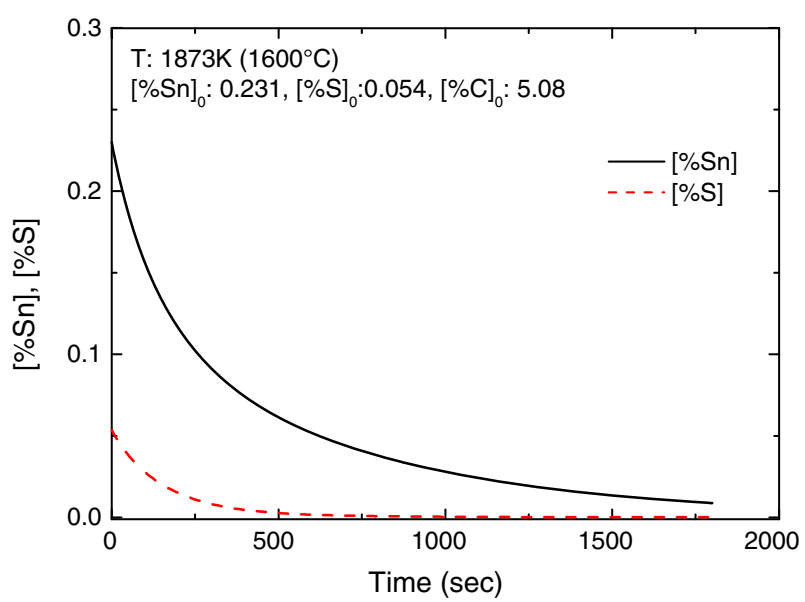

(a)

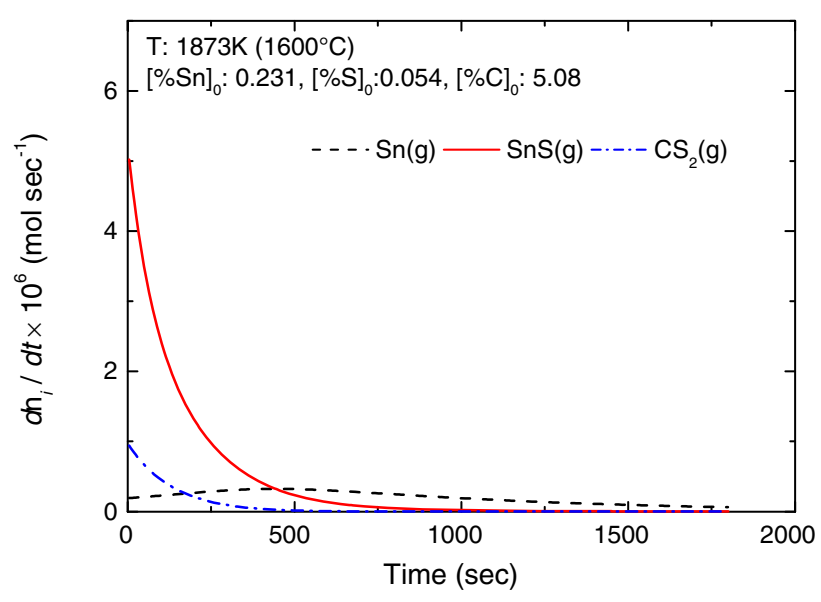

(b)

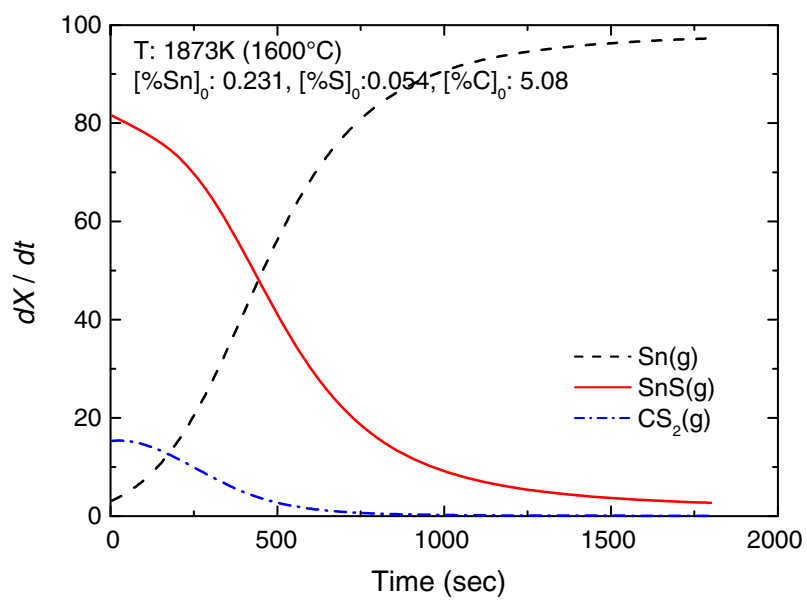

(c)

Fig. 14 Calculation results of evaporation for a Fe-C-S-Sn alloy at $1873 \mathrm{~K}\left(1600{ }^{\circ} \mathrm{C}\right)$. Mass of the alloy: $6 \times 10^{-4} \mathrm{~kg}$, [pct Sn] $]_{0}: 0.231$, [pct S $]_{0}: 0.054[\text { pct C] }]_{0}: 5.08$, respectively. (a) Changes of [pct Sn] and [pct S] during evaporation; (b) evaporation rates $\left(\right.$ mole s$^{-1}$ ) of $\mathrm{Sn}(\mathrm{g})$, $\mathrm{SnS}(\mathrm{g})$, and $\mathrm{CS}_{2}(\mathrm{~g})$, respectively; and $(c)$ fraction of each gas species during the evaporation.

is 120 seconds, and this is 15 times shorter than the case when $[\text { pct } \mathrm{S}]_{0}$ and $[\text { pct } \mathrm{C}]_{0}$ are zero, or 7 times shorter than the case when [pct $\mathrm{C}]_{0}$ is zero. 


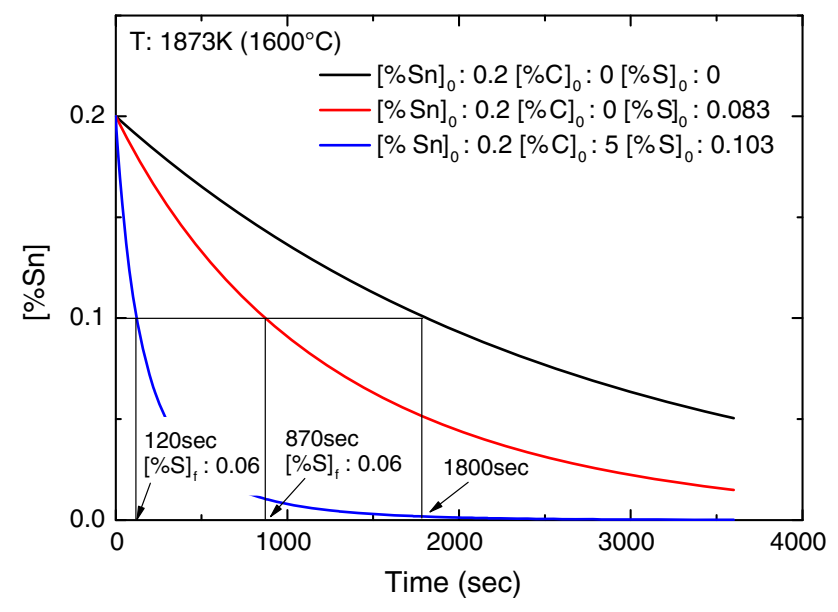

Fig. 15- Change of [pct Sn] in liquid steels with various initial components $(\mathrm{Fe}-0.2 \mathrm{Sn}, \mathrm{Fe}-0.083 \mathrm{~S}-0.2 \mathrm{Sn}$, and $\mathrm{Fe}-5 \mathrm{C}-0.103 \mathrm{~S}-0.2 \mathrm{Sn})$ at $1873 \mathrm{~K}\left(1600{ }^{\circ} \mathrm{C}\right)$ predicted by the evaporation model developed in the current study. See Section VII for details.

\section{CONCLUSIONS}

Evaporation of Sn from liquid Fe-C-S-Sn alloys was investigated at $1873 \mathrm{~K}\left(1600{ }^{\circ} \mathrm{C}\right)$, where mass transfers in gas phase and liquid phase did not significantly affect the reaction rate, to elucidate the reaction mechanism of the Sn evaporation and to quantitatively estimate the evaporation rate. An experimental investigation for a series of gas-liquid reactions was carried out and the results were further analyzed by a series of kinetic considerations. The following conclusions were obtained.

1. To elucidate role of $\mathrm{C}$ on the evaporation of $\mathrm{Sn}$, separate investigations were carried out for Fe-C-S and $\mathrm{Fe}-\mathrm{C}-\mathrm{Sn}$ alloys. It was found that $\mathrm{CS}_{2}(\mathrm{~g})$ was a evaporating gas species for liquid alloys containing $\mathrm{C}$ and S. Evaporation in the form of CS(g) was not appropriate to account for the experimental data obtained in the current study. The effect of $\mathrm{C}$ on the evaporation of $\mathrm{Sn}(\mathrm{g})$ from $\mathrm{Fe}-\mathrm{C}-\mathrm{Sn}$ alloy can be explained by the increase of activity coefficient of Sn by C.

2. A comprehensive evaporation rate model for the evaporation of $\mathrm{Sn}$ in the $\mathrm{Fe}-\mathrm{Sn}-\mathrm{S}$ alloy developed previously was expanded to incorporate the role of $\mathrm{C}$. The model equation takes into account (1) evaporation of $\mathrm{Sn}(\mathrm{g}), \mathrm{SnS}(\mathrm{g})$, and $\mathrm{CS}_{2}(\mathrm{~g})$ gas species simultaneously; (2) surface adsorption by $\mathrm{S}$; and (3) increase of activity coefficients of Sn and S by C. The model equation could explain the experimental data (change of [pct $\mathrm{Sn}$ ] and [pet S] in liquid alloys) successfully. Moreover, the model equation can be used to analyze evaporation reaction in the $\mathrm{Fe}-\mathrm{C}-\mathrm{S}-\mathrm{Sn}$ alloy in more detail, such as a change of the evaporation mode.

3. The established model can be further used to find optimal S content in order to increase $\mathrm{Sn}$ removal rate.

\section{ACKNOWLEDGMENT}

This research was financially supported by POSCO Ltd. through Steel Innovation Program.

\section{NOMENCLATURE}

$f_{i} \quad$ Activity coefficient of $i$ in liquid alloy

$f_{i}^{\circ} \quad$ Activity coefficient of $i$ in liquid alloy without

$\rho \quad$ Density of melt $\left(\mathrm{kg} \mathrm{m}^{-3}\right)$

$A \quad$ Area of reaction surface $\left(\mathrm{m}^{2}\right)$

$e_{\mathrm{S}}^{\mathrm{C}} \quad$ Interaction parameter of $\mathrm{C}$ for $\mathrm{S}$

$i^{\mathrm{S}}$

$i^{\mathrm{i}}$

[pet $i$ ] Mass percent of species $i$ in liquid alloy at time Species $i$ dissolved in liquid alloy Species $i$ at the interface

[pet $i]_{0} \quad \begin{aligned} & t \\ & \text { Mass percent of species } i \text { in liquid alloy at }\end{aligned}$ initial state $(t=0)$

[pet $i]_{\mathrm{f}} \quad$ Mass percent of species $i$ in liquid alloy at final state

$k_{\mathrm{CS}} \quad$ Apparent reaction rate constant of

Reaction [9] for CS(g) evaporation $\left(\mathrm{m} \mathrm{s}^{-1}\right)$

$k_{\mathrm{CS}}^{\mathrm{R}} \quad$ Chemical rate constant of Reaction [9] for $\mathrm{CS}(\mathrm{g})$ evaporation of fully open surface $\left(\mathrm{m}^{4} \mathrm{~mol}^{-1} \mathrm{~s}^{-1}\right)$

$k_{\mathrm{CS}}^{\mathrm{r}} \quad$ Residual rate constant of Reaction [9] for CS $(\mathrm{g})$ evaporation $\left(\mathrm{m}^{4} \mathrm{~mol}^{-1} \mathrm{~s}^{-1}\right.$

$k_{\mathrm{CS}_{2}} \quad$ Apparent reaction rate constant of Reaction

[13] for $\mathrm{CS}_{2}(\mathrm{~g})$ evaporation $\left(\mathrm{m} \mathrm{s}^{-1}\right) \mathrm{f}$

$k_{\mathrm{CS}_{2}}^{\mathrm{R}} \quad$ Chemical rate constant of Reaction [13] for $\mathrm{CS}_{2}(\mathrm{~g})$ evaporation of fully open surface $\left(\mathrm{m}^{7} \mathrm{~mol}^{-2} \mathrm{~s}^{-1}\right.$

$k_{\mathrm{CS}_{2}}^{\mathrm{r}} \quad$ Residual rate constant of Reaction [13] for $\mathrm{CS}_{2}(\mathrm{~g})$ evaporation $\left(\mathrm{m}^{7} \mathrm{~mol}^{-2} \mathrm{~s}^{-1}\right)$

$k_{\mathrm{Sn}} \quad$ Apparent rate constant of Reaction [1] for $\mathrm{Sn}(\mathrm{g})$ evaporation $\left(\mathrm{m} \mathrm{s}^{-1}\right)$

$k_{\mathrm{Sn}}^{\mathrm{R}} \quad$ Chemical rate constant of Reaction [1] for

$\mathrm{Sn}(\mathrm{g})$ evaporation of fully open surface $\left(\mathrm{m} \mathrm{s}^{-1}\right)$

$k_{\mathrm{Sn}}^{\mathrm{R}, \mathrm{o}} \quad$ Chemical rate constant of Reaction [1] for $\mathrm{Sn}(\mathrm{g})$ evaporation of fully open surface in $\mathrm{Fe}-\mathrm{Sn}$ alloy $\left(\mathrm{m} \mathrm{s}^{-1}\right)$

$k_{\mathrm{SnS}} \quad$ Apparent reaction rate constant of Reaction [2] for $\mathrm{SnS}(\mathrm{g})$ evaporation $\left(\mathrm{m} \mathrm{s}^{-1}\right)$

$k_{\mathrm{SnS}}^{\mathrm{R}} \quad$ Chemical rate constant of Reaction [2] for $\mathrm{SnS}(\mathrm{g})$ evaporation of fully open surface $\left(\mathrm{m}^{4} \mathrm{~mol}^{-1} \mathrm{~s}^{-1}\right)$

$k_{\mathrm{SnS}}^{\mathrm{r}} \quad$ Residual rate constant of Reaction [2] for $\mathrm{SnS}(\mathrm{g})$ evaporation $\left(\mathrm{m}^{4} \mathrm{~mol}^{-1} \mathrm{~s}^{-1}\right)$

$K_{\mathrm{S}} \quad$ Adsorption coefficient of $\mathrm{S}$

$\mathrm{M}_{i} \quad$ Molecular weight of element $i\left(\mathrm{~kg} \mathrm{~mol}^{-1}\right)$

$n_{i} \quad$ Number of moles of species $i$ (mol)

$t \quad$ Reaction time (seconds)

$V \quad$ Volume of melt $\left(\mathrm{m}^{3}\right)$

\section{REFERENCES}

1. E.T. Stephenson: J. Met., 1974, vol. 26, pp. 48-52.

2. H.A. Persson and R. Harris: Erzmetall, 1984, vol. 37, pp. 174-8.

3. L. Savov and D. Janke: ISIJ Int., 2000, vol. 40, pp. 654-63. 
4. T. Matsuo, K. Maya, T. Nishi, K. Shinme, A. Ueno, and S. Anezaki: ISIJ Int., 1996, vol. 36, pp. S62-5.

5. T. Matsuo: Tetsu-to-Hagane, 2000, vol. 86, pp. 741-7.

6. N. Tokumitsu: CAMP-ISIJ, 1990, vol. 3, p. 1184.

7. L. Savov and D. Janke: ISIJ Int., 2000, vol. 40, pp. 95-104.

8. K. Ito, M. Kishimoto, and K. Mori: Tetsu-to-Hagané, 1992, vol. 78 , pp. 1441-8.

9. C.N. Esimai: Scand. J. Metall., 1987, vol. 16, pp. 267-70.

10. R. Morales and N. Sano: Ironmak. Steelmak., 1982, vol. 9, pp. 64 76.

11. H. Katayama: CAMP-ISIJ, 1991, vol. 4, p. 985.

12. X. Liu and J.H.E. Jeffes: Ironmak. Steelmak., 1988, vol. 15, pp. 21-6.

13. X. Liu and J.H.E. Jeffes: Ironmak. Steelmak., 1988, vol. 15, pp. 27-32.

14. S.-H. Jung, Y.-B. Kang, J.-D. Seo, J.-K. Park, and J. Choi: Metall. Mater. Trans. B, 2014, DOI:10.1007/s11663-014-0163-3.
15. S.-H. Jung, Y.-B. Kang, J.-D. Seo, J.-K. Park, and J. Choi: Metall. Mater. Trans. B, 2014, DOI:10.1007/s11663-014-0177-x.

16. G. Sigworth and J. Elliott: Metall. Sci., 1974, vol. 8, p. 298.

17. C. Wang, T. Nagasaka, M. Hino, and S. Ban-Ya: ISIJ Int., 1991, vol. 31 , pp. $1336-44$.

18. Japan Society for the Promotion of Science: Steelmaking Data Sourcebook, Gordon and Breach Science Publishers, Montreux, 1984.

19. M. Chase: NIST-JANAF Thermochemical Tables, 4th ed., NIST, Gaithersburg, MD, 1998

20. K. Sekino, T. Nagasaka, and R.J. Fruehan: ISIJ Int., 2000, vol. 40, pp. 315-21.

21. P. Glaws and R.J. Fruehan: Metall. Trans. B, 1985, vol. 16B, pp. 551-9.

22. I. Langmuir: J. Am. Chem. Soc., 1918, vol. 40, pp. 1361-403. 